\title{
The Use of Hydrograph Analysis to Evaluate the Groundwater Contribution to Tigris River Flow at Mosul City
}

\author{
Thabit D. Mahder-Bashi \\ Department of Geology \\ College of Science \\ Mosul University
}

\author{
Mohammed F. Omar khattb \\ Remote Sensing Center \\ Mosul University
}

(Received 3/7/2008, Accepted 26/2/2009)

\begin{abstract}
The flow regime of the River Tigris has been studied during ten successive years from 1975 - 1984. The annual hydrographs of the river were analyzed to determine the ground water components by considering the general form of the river regime, and the minimum flows during recession.

Master recession curve was derived from the river flow records of the studied catchment area by combining the characteristics of various recession records, and used to check the separation of components contributing to the river flow and also indicate the number of aquifers involve in contributing the ground water to the river.

Four major aquifers outside the study area and within the Turkish territory appeared from the analysis contributing ground water of about $58 \%$ to $75 \%$ percent of the total flow during the ten years period.

The total volume of water in storage from the beginning of recession was also determined along the ten years and was varying between $1.0 \times 10^{9}-6.0 \times 10^{9} \mathrm{~m}^{3} /$ year.

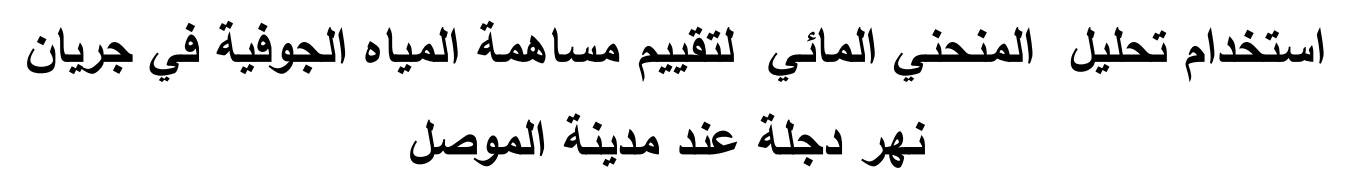

$$
\text { محمد فوزي عمر خطاب التحسس النائي }
$$$$
\text { ثابت داؤد محضر باشي }
$$$$
\text { قسم علوم الأرض داؤ محنر باتصي }
$$$$
\text { كلية العلوم }
$$$$
\text { جامعة الموصل }
$$

الملخص

تم دراسة نظام جريان نهر دجلة خلال عشر سنوات متتالية ابتدأ من 19 و ولغاية ـ191 ـ إذ تم

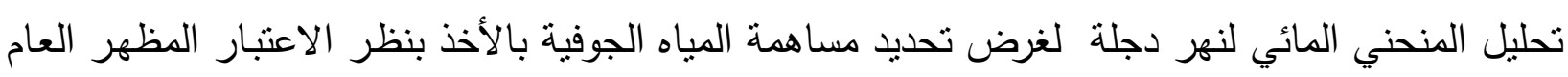

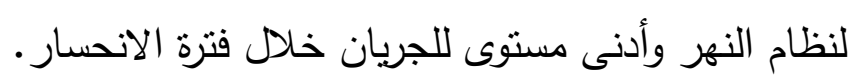




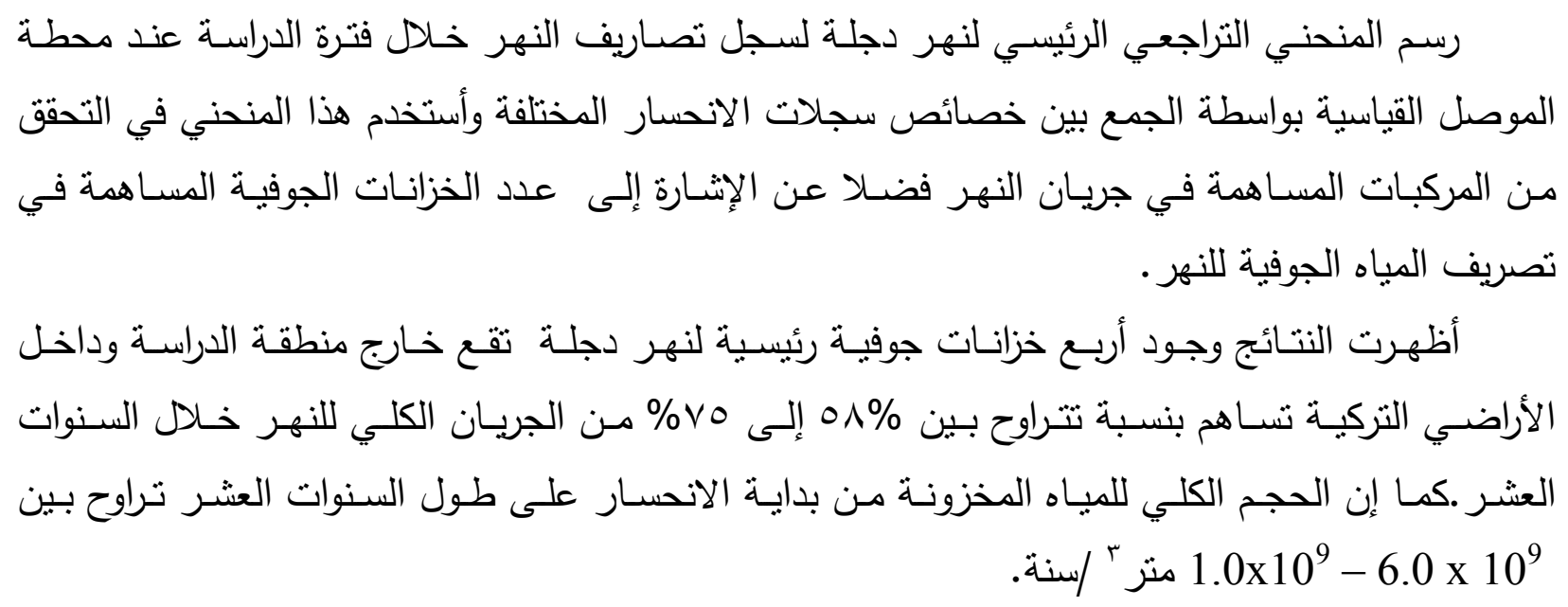

\section{INTRODUCTION}

The Tigris River (Dijlah in Arabic) is the eastern member of the two great rivers that define Mesopotamia, along with the Euphrates. The Tigris river is approximately $1900 \mathrm{~km}$ (1,180 miles) long and drains an area of more than $371562 \mathrm{~km}^{2}, 53052 \mathrm{~km}^{2}$ in Turkey, $175386 \mathrm{~km}^{2}$ in Iran, $948 \mathrm{~km}^{2}$ in Syria, and $142175 \mathrm{~km}^{2}$ in Iraq, (UNEP,2001) (Fig. 1). It rises from the southeastern part of Turkey on the southern slopes of the Taurus Mountains of eastern Turkey enters the Iraqi Turkish border at Fiesh khabur and flowing in a generally southeasterly direction until it joins the Euphrates near Al Qurna in southern Iraq. The Tigris river is the side of many major cities (Wikipedia, 2007), (MSN, 2006).

Mosul city is one of the major cities in Iraq, situated at the northern part of the country, on both sides of the Tigris. It includes the discharge gauge station of the river which is located on the middle of the city near the old bridge. It is considered as one of the most important stations along the Tigris River, which was established in the early seventies, (Fig. 2).

The Tigris River running through outcropped strata, of many geological formations, (Fig. 3), in Iraq; Fatha Formation (lower Fars) is one of the most aerially widespread and economically important formations in Iraq, it comprises anhydrite, gypsum, and salt, interbedded with limestone and marl. Injana Formation (upper Fars) compises fine grained pre-molasse sediments deposited initially in coastal areas, and later in a fluviolacustrine system. Mukdadiya Formation (lower Bakhtiary) comprises up to $200 \mathrm{~m}$ of fining upwards cycles of gravely sandstone, sandstone and red mudstone. Bai Hassan Formation (upper Bakhtiary) consists of conglomerate, sandstone and claystone, (Jassim and Goff, 2006).

In spite of the importance of the Tigris River as one of major water resource in Iraq, there is a lack of studying its components and sources. The current research aimes to study the River discharge at Mosul gauge station, by the analysis of hydrograph for the ten years, from (1975- 1984) before the construction of the Mosul Dam, so as to observe the effects of Mosul dam on the values of the discharge of the Tigris river after that period. The techniques of master recession curve is used to indicate the source and contribution of the base flow (ground water) to the river. 
The Use of Hydrograph Analysis to Evaluate The Groundwater.....

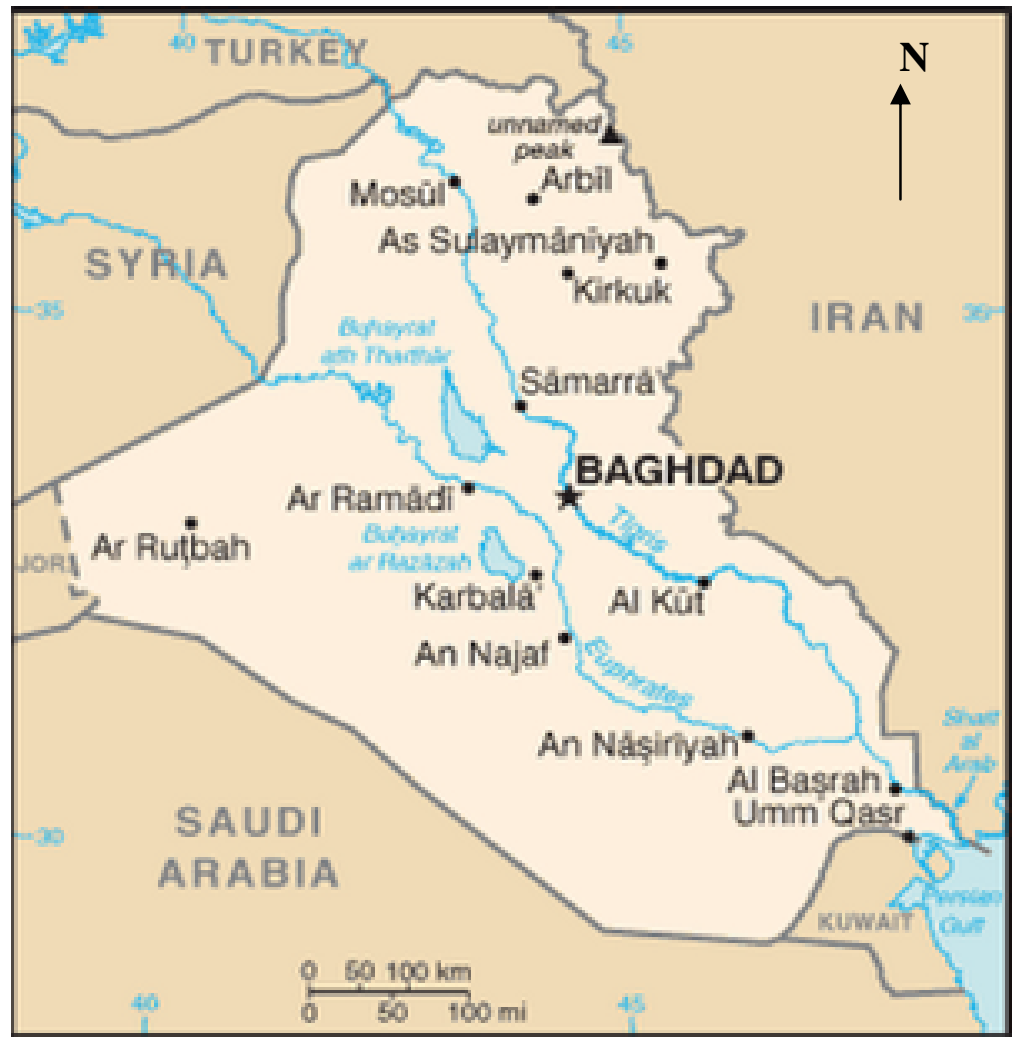

Fig. 1: The Tigris and Euphrates river basin.

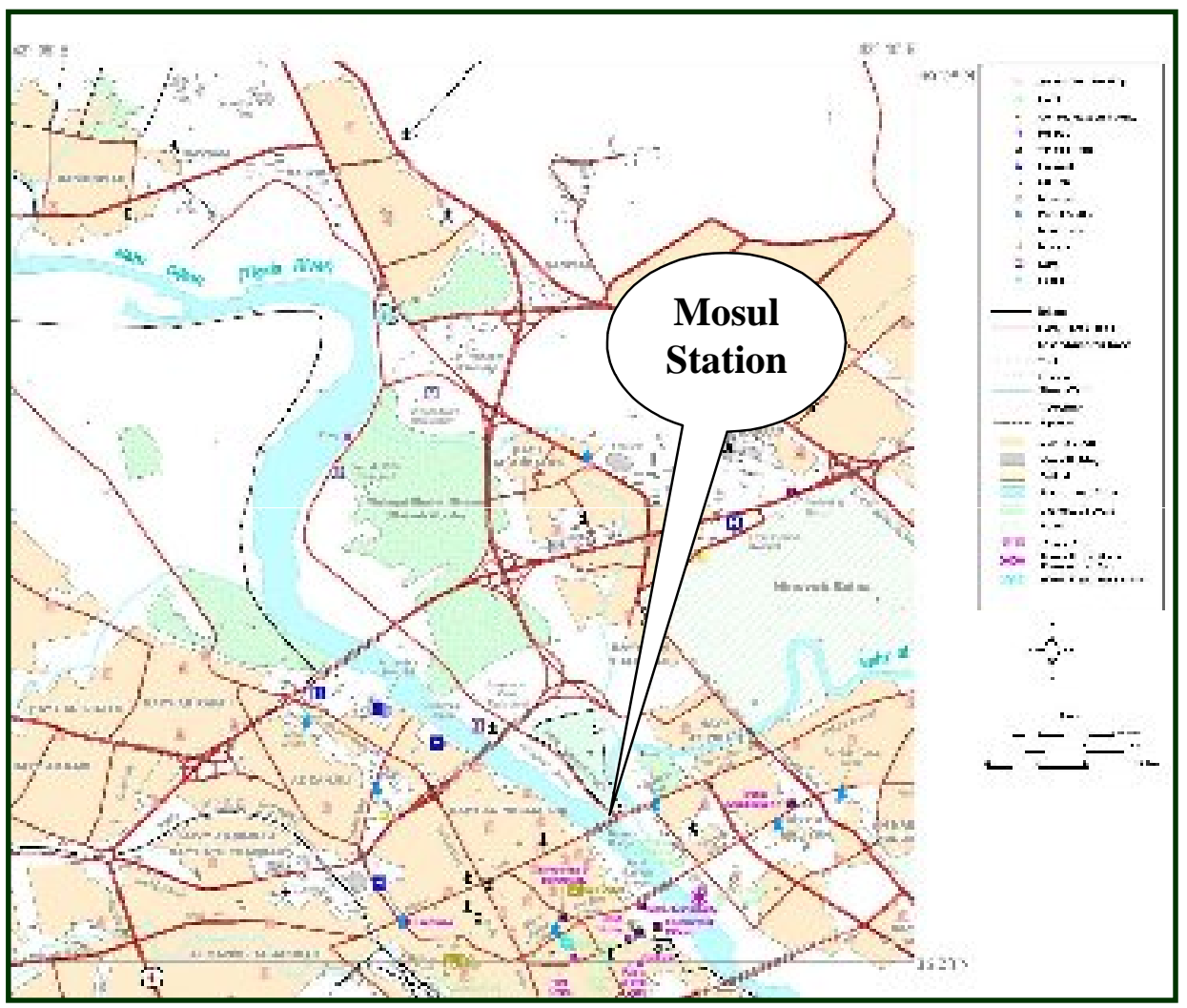

Fig. Y: Location map of Mosul Gauge station. 


\section{ANALYSIS OF TIGRIS HYDROGRAPH AT MOSUL STATION}

A hydrograph is a continuous plot of instantaneous discharge Vs. time. It results from a combination of physiographic and meteorologic conditions in a watershed and represents the integrated effects of climate, hydrologic losses, surface runoff, interflow and ground water flow (Bedient and Huber, 1988).

Integration of the area beneath the hydrograph between any two points in time, gives the total volume of water passing during that time interlay. Therefore, hydrographs provide informations on volumes of surface runoff, ground water flow and interflow from interactive water that is temporarily stored in the soil and laterally enters the stream via upper soil layers (Warren and Gary, 2007).

Figure (4) shows the annual Tigris hydrographs, with stream flow (discharge) in cubic meter per second on the y-axis and time in days on the x-axis for the period, between (1975 to 1984) before the construction of the Mosul Dam, so as to observe the effects of Mosul dam on the values of the discharge of the Tigris river after that period. In general, this figure shows the rising limb of annual hydrographs take a rise in the period between end of February and beginning of March. And also notes that the end of the recession limb of annual Tigris hydrograph starts almost at the beginning of June during the years of study.

The peaks (crest) of the hydrographs between (1975 to 1984) start from the beginning of April until May. Some variations are noticed, this is may be due to the sudden rain storms occurring before or after this time.

\section{SEPARATION OF HYDROGRAPH}

The basic process of analyzing a hydrograph begins by separating the components of runoff and base flow. This is done to facilitate analysis, but it also arises out the different purposes that hydrograph analysis may serve. Investigators of flooding are primarily interested in the storm flow component, whereas investigators of ground water or long-term effects of water fluxes are more interested in the base flow component (Reddy, 2005).

The hydrographs of the Tigris river have been analyzed to determine the ground water component by considering the general form of the river regime, and the minimum flows during recession period (Fig. 4). The first step of determination of the groundwater flow or base flow is to separate the base flow from direct runoff by direct method (straight line method). The volume of ground water is then determined (Linsley, et al., 1982). This is simply a summation of the products of an arbitrary unit of time $(d t)$ and the height of the direct runoff ordinate at the center of the selected time interval. The ground water component (base flow) for aquifer discharge into the river Tigris for the years (1975-1984) is shown in (Table 1).

\section{RECESSION CURVE ANALYSIS}

The recession curve is the specific part of the flood hydrograph (and the rainfall event) where stream flow diminishes, refer to Base flow. The slope of the recession curve flattens over time from its initial steepness as the quick flow component passes and base flow becomes dominant. A recession period lasts until stream flow begins to increase again due to subsequent rainfall. Hence, recession curves are the parts of the hydrograph 
The Use of Hydrograph Analysis to Evaluate The Groundwater.....

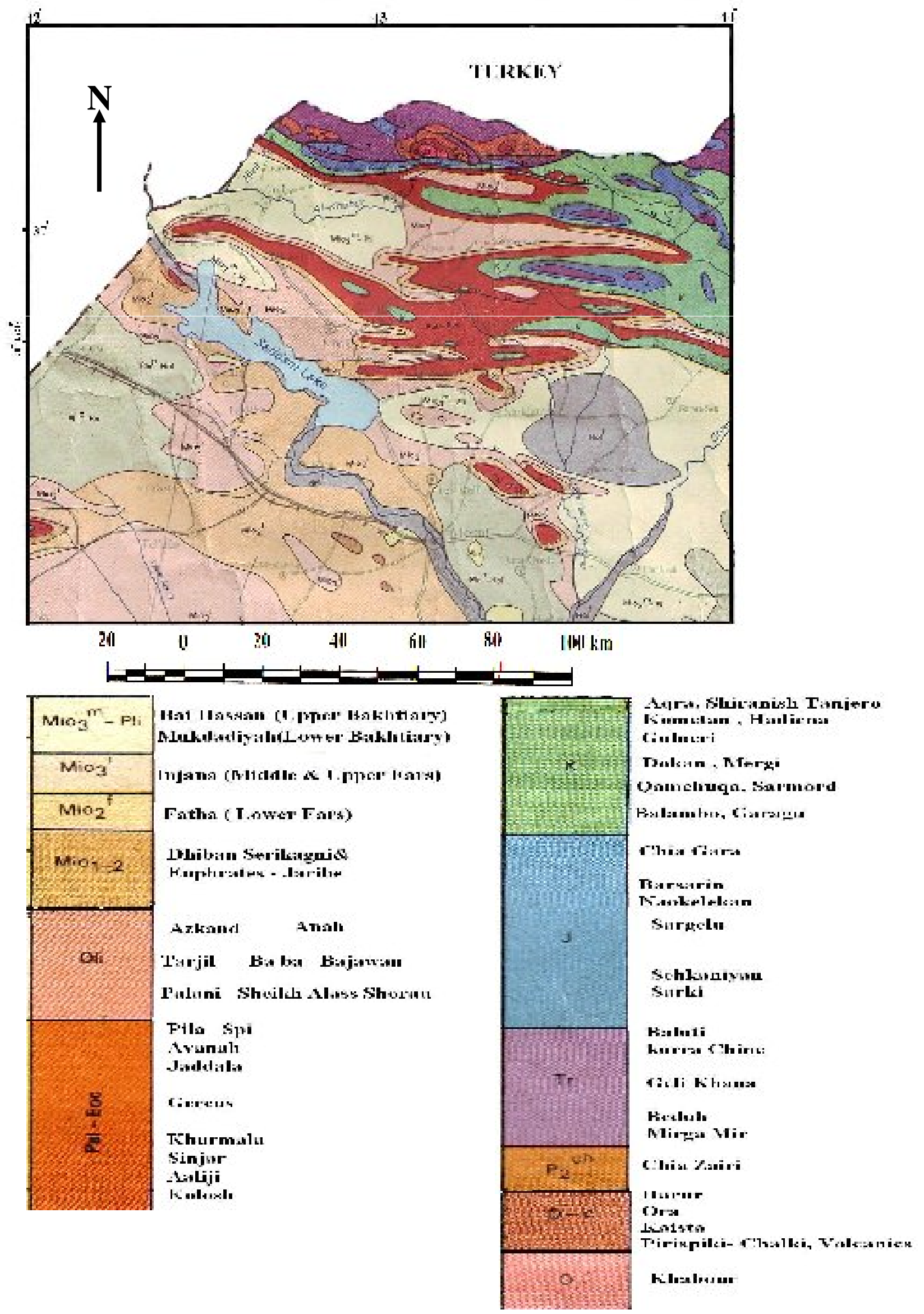

Fig. 3: Geological map of Northren Iraq (Jassim et al., 1990). 
that are dominated by the release of water from natural storages, typically assumed to be groundwater discharge (C.W., 2008).

In the current study the semi-log method used to separate parts of hydrograph, where the tail end of hydrograph plots as a straight line that represent recession curve (Raghunath, 2006), (Fig. 5). The total potential ground water discharge calculated by applying the following equation (Meyboom, 1961).

$$
\mathrm{V}_{\mathrm{p}}=\frac{Q_{0} t_{1}}{2.3}
$$

Where:

$\mathrm{V}_{\mathrm{p}}=$ is the total potential ground water discharge.

$\mathrm{Q}_{\mathrm{o}}=$ is the measured discharge at time $\mathrm{t}=0$.

$\mathrm{t}_{1}=$ the time per one log cycle.

The abnormal values for discharge at 1976, 1978 and 1981 in the figure (5) is a printing error from Directorate of Irrigation Nineveh records.

Estimation of the total amounts of potential base flow $\left(\mathrm{V}_{\mathrm{t}}\right)$ that represented the volume of discharge from the time of beginning recession curve until end of dry season $(\mathrm{t})$ is by the following equation

$$
\mathrm{V}_{\mathrm{t}}=\frac{V_{p}}{10^{\frac{t}{t_{1}}}}
$$

The difference between the remaining potential ground water discharge at the end of a given base flow recession and the total potential ground water discharge at the beginning of the next recession represents the recharge (base flow storage) that takes place between two recessions.

$$
\mathrm{V}_{\mathrm{p}}-\mathrm{V}_{\mathrm{t}}=\text { Base flow storage. }
$$

Table 1: Ratios of base flow contribution and runoff for the period of study

\begin{tabular}{|c|c|c|}
\hline Year & Runoff $\%$ & Base flow $\%$ \\
\hline 1975 & 42 & 58 \\
\hline 1976 & 34 & 65 \\
\hline 1977 & 41 & 59 \\
\hline 1978 & 33 & 67 \\
\hline 1979 & 29 & 71 \\
\hline 1980 & 25 & 75 \\
\hline 1981 & 33 & 67 \\
\hline 1982 & 37 & 63 \\
\hline 1983 & 30 & 70 \\
\hline 1984 & 31 & 69 \\
\hline
\end{tabular}

Table (2) shows the values calculated from the recession curve for Tigris river annual hydrograph during the period of study and (Fig. 6) illustrates how to measure. 

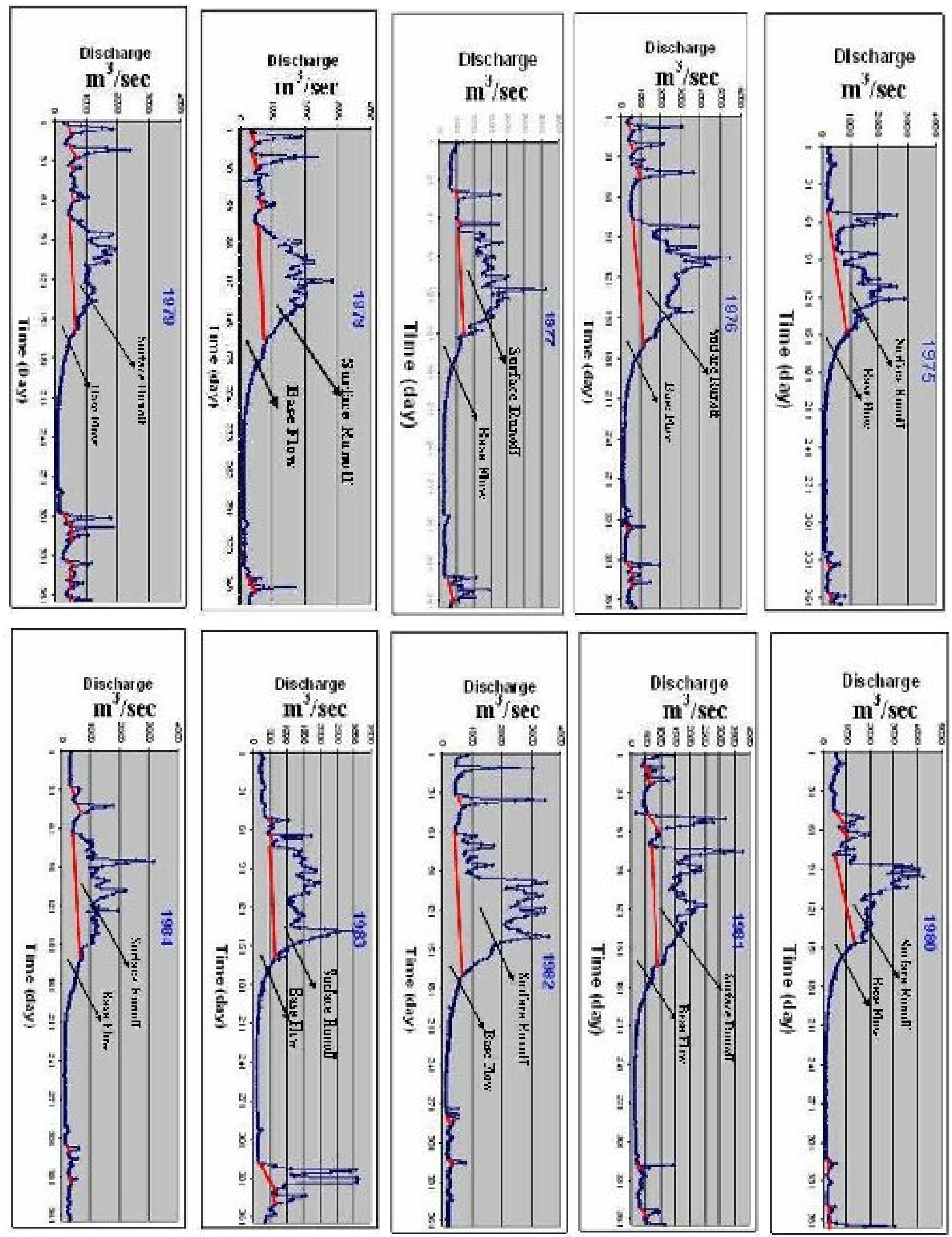

Fig. 4: Hydrographs separation of Tigris river for the period 1975 to 1984. (data source: Directorate of Irrigation Nineveh) 
Thabit D. Mahder-Bashi and Mohammed F. Omar khattb
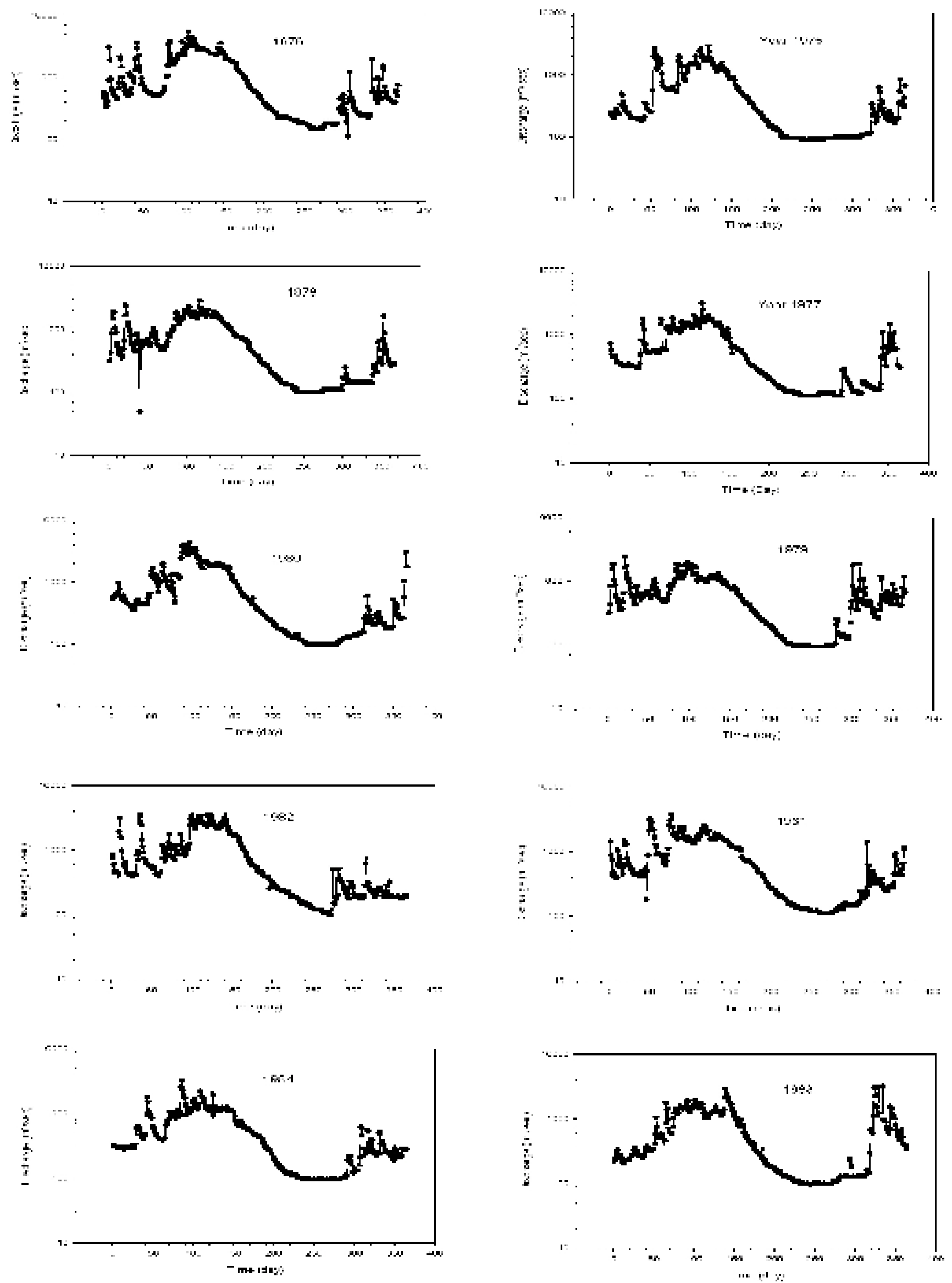

Fig. 5: Semi log methods to separate parts of Tigris Hydrographs during the period 1975 to 1984 . 


\section{MASTER RECESSION CURVE TECHNIQUES}

Master recession curve techniques have been used to check the separation of components distributing to the river flow and also indicate the difference in the aquifer which contribute the ground water to the river. This curve involves various recession segment which were taken from the hydrographs of the river from (1975- 1984). These segments matched one another until a series of curves are assembled, (Figure 7), and the upward curving parts of individual arcs are disregarded. The resulting continues arc of curves is a mean or normal depletion curve, (Fig. 8), and by taking points from the common graph and plotted on semi logarithmic paper see (Fig. 9).

Table 2: Values of $\mathrm{V}_{\mathrm{p}}, \mathrm{V}_{\mathrm{t}}$ and base flow storage of Tigris river through periods of study.

\begin{tabular}{|c|c|c|c|c|c|c|}
\hline Year & $\begin{array}{c}\mathbf{Q}_{\mathbf{o}} \\
\left(\mathbf{m}^{\mathbf{3}} / \mathbf{s e c}\right)\end{array}$ & $\begin{array}{c}\mathbf{t}_{\mathbf{1}} \\
(\mathbf{d a y})\end{array}$ & $\begin{array}{c}\mathbf{t} \\
(\mathbf{d a y})\end{array}$ & $\begin{array}{c}\mathbf{V}_{\mathbf{p}} \\
\left(\mathbf{m}^{\mathbf{3}}\right)\end{array}$ & $\begin{array}{c}\mathbf{V}_{\mathbf{t}} \\
\left(\mathbf{m}^{\mathbf{3}}\right)\end{array}$ & Base flow storage $\mathbf{( m}^{\mathbf{3}} \mathbf{)}$ \\
\hline 1975 & 800 & 72 & 175 & $2.1 \times 10^{9}$ & $2.2 \times 10^{9}$ & $0.1 \times 10^{9}$ \\
\hline 1976 & 2700 & 60 & 120 & $6.0 \times 10^{9}$ & $6.0 \times 10^{9}$ & $6.0 \times 10^{9}$ \\
\hline 1977 & 600 & 100 & 130 & $2.2 \times 10^{9}$ & $2.1 \times 10^{9}$ & $0.1 \times 10^{9}$ \\
\hline 1978 & 490 & 77 & 120 & $1.4 \times 10^{9}$ & $1.4 \times 10^{9}$ & $1.4 \times 10^{9}$ \\
\hline 1979 & 550 & 70 & 111 & $1.4 \times 10^{9}$ & $1.4 \times 10^{9}$ & $1.4 \times 10^{9}$ \\
\hline 1980 & 550 & 90 & 114 & $1.8 \times 10^{9}$ & $1.8 \times 10^{9}$ & $1.8 \times 10^{9}$ \\
\hline 1981 & 600 & 72 & 112 & $1.6 \times 10^{9}$ & $1.6 \times 10^{9}$ & $1.6 \times 10^{9}$ \\
\hline 1982 & 600 & 110 & 96 & $2.4 \times 10^{9}$ & $2.4 \times 10^{9}$ & $2.4 \times 10^{9}$ \\
\hline 1983 & 400 & 80 & 115 & $1.2 \times 10^{9}$ & $1.2 \times 10^{9}$ & $1.2 \times 10^{9}$ \\
\hline 1984 & 475 & 60 & 100 & $1.0 \times 10^{9}$ & $1.0 \times 10^{9}$ & $1.0 \times 10^{9}$ \\
\hline
\end{tabular}

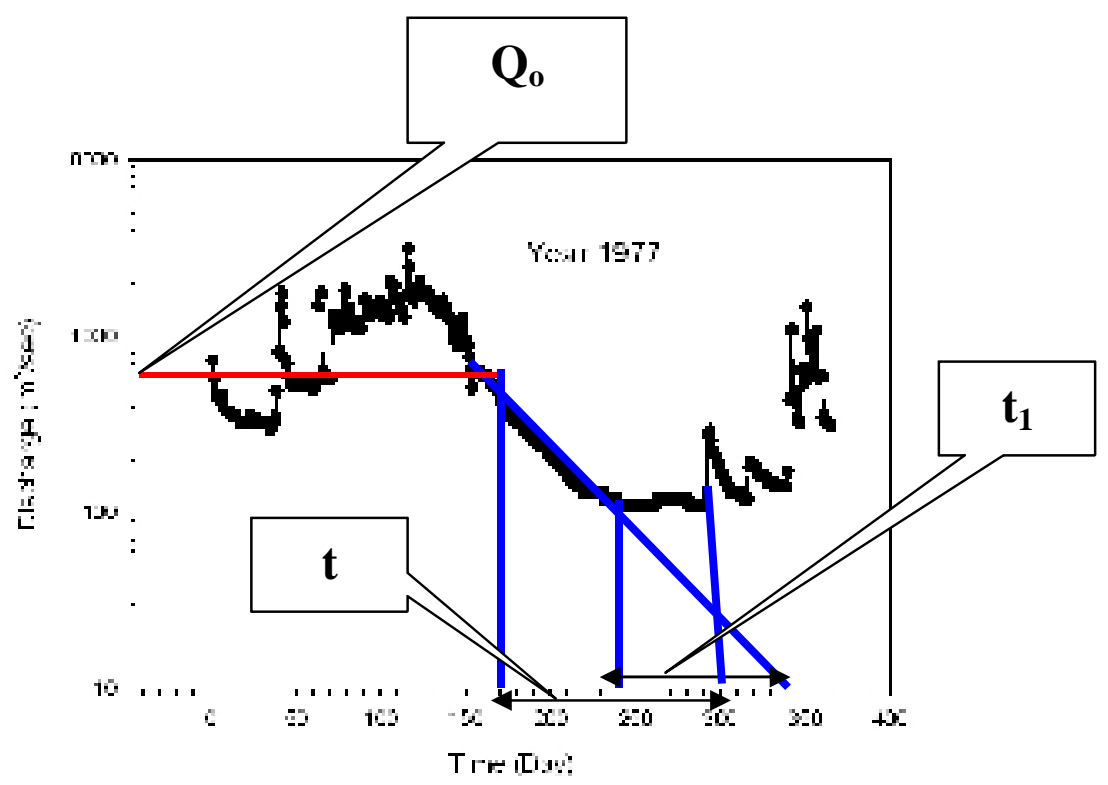

Fig. 6: Shows the analysis of recession curve semi log method for 1977 Tigris River hydrograph. 
The resulted graph used to determine the recession constant $(\mathrm{k})$ for each segment that can be expressed as a mathematical function (Barns, 1939).

The simplest function in the basic exponential equation of the flow

$\mathrm{Q}_{\mathrm{t}}=\mathrm{Q}_{0} \mathrm{e}^{-\mathrm{at}}$ or $\mathrm{Q}_{\mathrm{t}}=\mathrm{Q}_{0} \mathrm{~K}^{\mathrm{t}}$

Where $\mathrm{Q}_{\mathrm{t}}=$ initial discharge

$\mathrm{e}=$ base of the natural logarithmic

$\mathrm{a}=$ constant

$\mathrm{t}=$ time interval

$\mathrm{K}=$ constant representing $\left(\mathrm{e}^{-\mathrm{a}}\right)$

Equation (4) can also be written as

$\log \mathrm{Q}_{\mathrm{t}}=\mathrm{t} \log \mathrm{k}+\log \mathrm{Q}_{\mathrm{o}}$

And plot as straight line on semi - log paper graph paper, the resulted graph used to determine the recession constant $(\mathrm{k})$ for each segment. Every break point on the line is caused by change in a characteristics of underground reservoir and refers to the number of aquifers that feed of river.

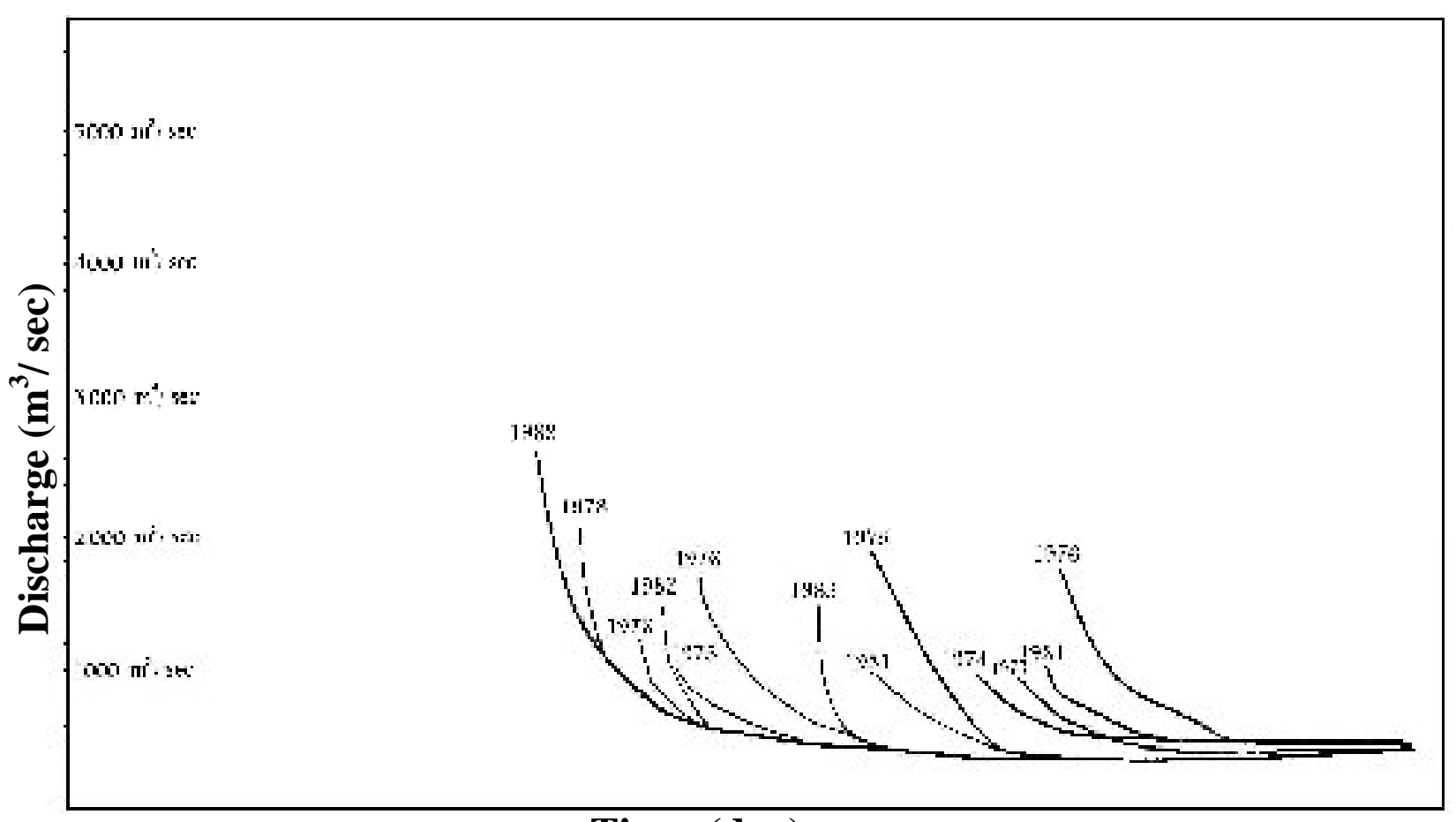

\section{Time (day)}

Fig. 7: Derivation of a master recession curve for Tigris river during the study period. 


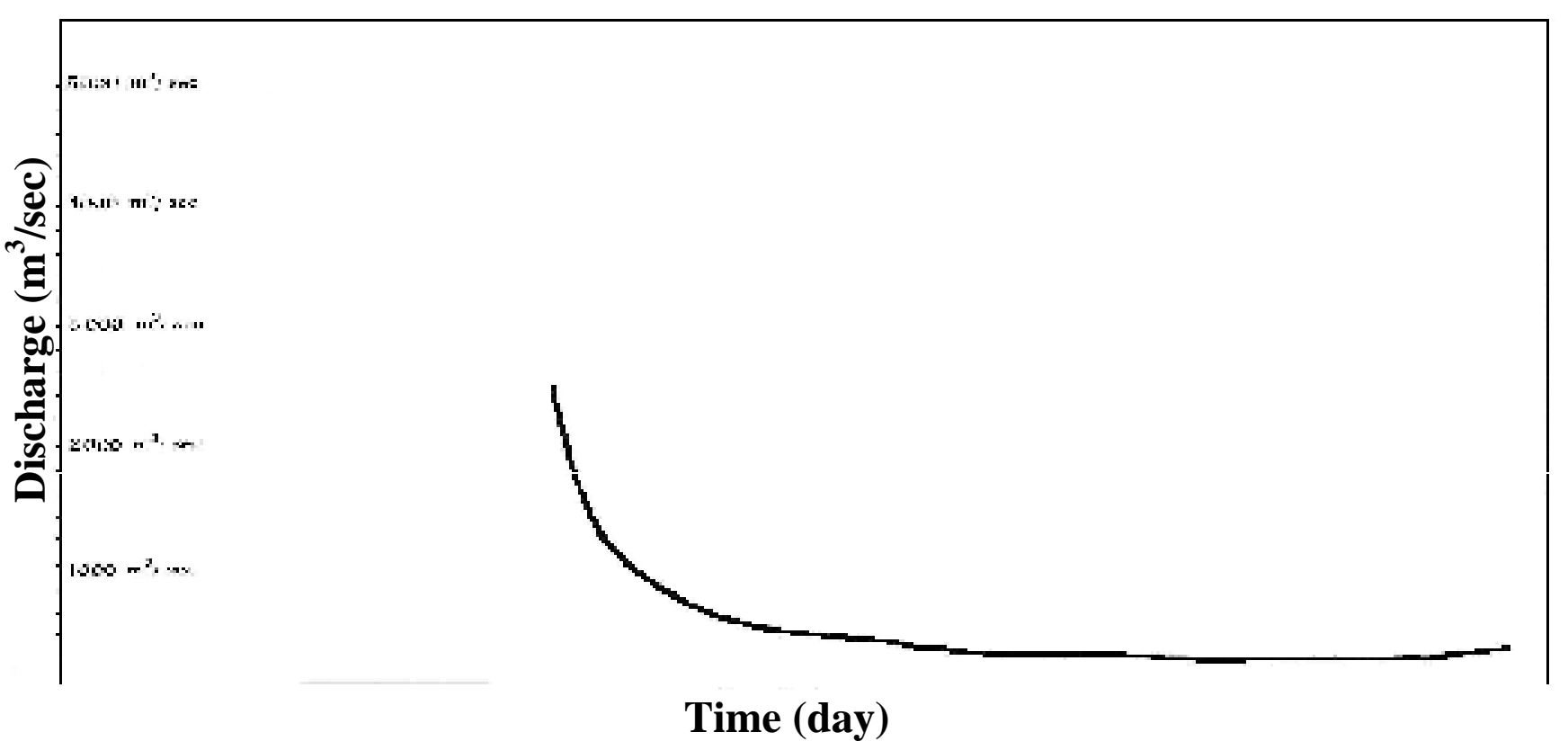

Fig. 8: Linear plot of master recession curve of Tigris river during the study period.

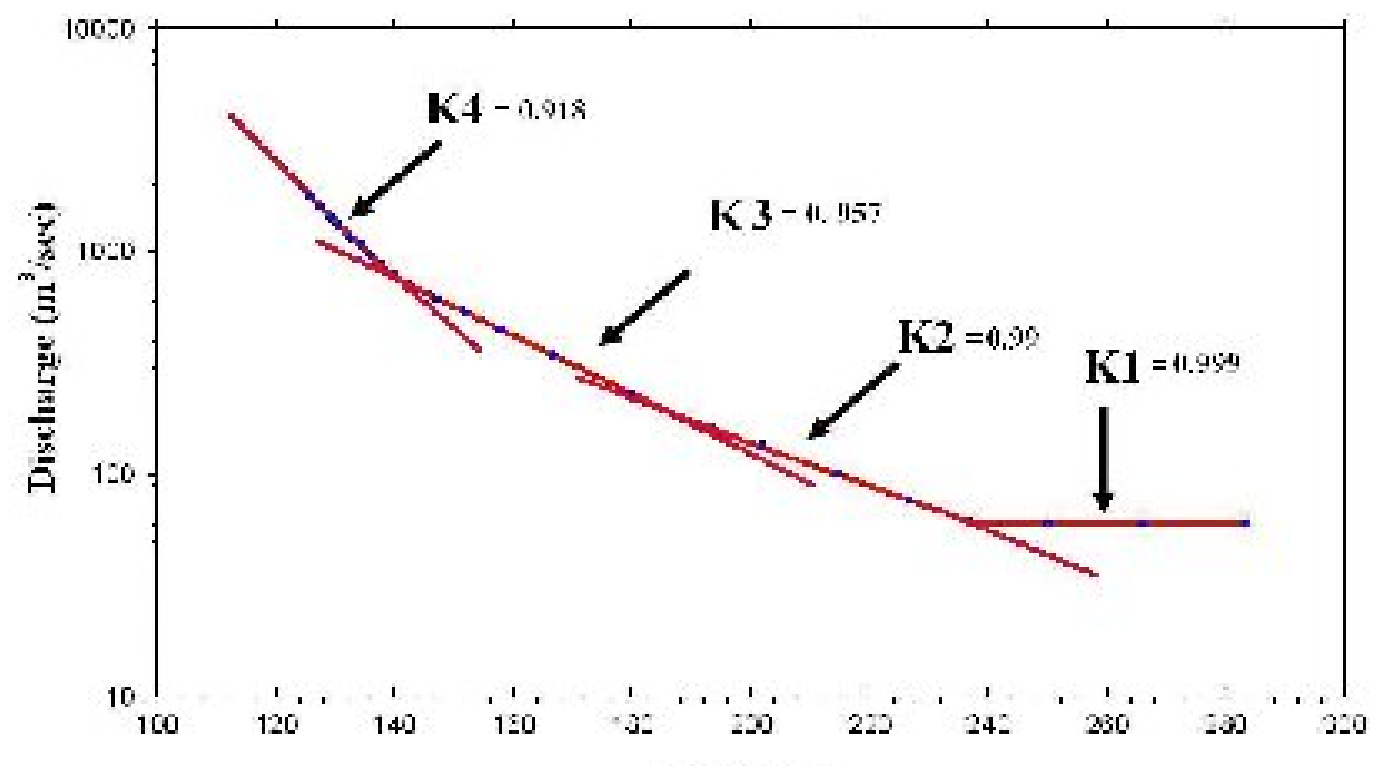

Time (day)

Fig. 9: Semi-logarithmic plot recession curve of Tigris river show change with recession coefficient.

According to (Barns, 1939) $\mathrm{k}=0.3$ surface flow, 0.65 interflow, and $0.90-0.99$ indicate ground water or base flow(Mahder - Bashi, 1976). From the master recession curve (Fig. 9), shows four segments where k ranging between 0.918 to 0.999 , indicating ground water contributing from four different aquifer, have different permeabilities. 


\section{CONCLUSION}

The master recession curve serves as an excellent tool for the study of ground water discharge, depends on reasonably accurate separation of base runoff from surface runoff on stream. Hydrograph and this techniques can be used as a useful tool in regional ground water studies.

The results obtained from this study is shown in (Table 1); the base flow ranges from $58 \%$ to $75 \%$ of the total runoff and the base flow storage during the years of study ranging from $0.1 \times 10^{9}$ to $6.0 \times 10^{9}$ (Table 2), indicating these contribution came from high permeability and huge aquifer which are not available inside Iraq territory. The contribution of the aquifer inside Iraq seems to be insignificant and its results do appear at the main aquifer contribution of ground water to the river as shown in (Fig. 9). Thus the number of aquifers and characteristics of underground reservoir can be determined through the master recession curve techniques. The Tigris river from the source until Mosul gauge station has four aquifers that feed the base flow located inside Turkey.

\section{REFERENCES}

Badient, Philip B. and Huber, Wayne C., 1988. Hydrology of Flood Plain Analysis. Addison - Wesely Publisher Co., 650p.

Barnes, B.S., 1939. The Structure of Discharge Recession Curves, Trans. Amer. Soc. Agri. Eng. Vol. 7, pp . 454 - 600.

C.W. Connected Water. 2008: Managing the Linkages Between Surface Water and Ground Water. Australian Government.

Available at www.connectedwater.gov.au/framework/recession_analysis.php

Jassim, Saad Z. and Goff, Jeremy C.,2006. Geology of Iraq. Publisher Dolin, Czech Republic. 341p.

Jassim, Saad Z.; Hagopian, Dikran, H., and Al- Hashimi, Hisham A. J., 1990. Geological Map of Iraq. Published by Geological Survey and Mineral Investigation. Baghdad.

Linsley, R.K. JR; Kohler, M.A. and Paulhus, J.L.H., 1982. Hydrology for Engineers, Third Edition. McGraw - Hill , Inc., 508p.

Mahder-Bashi, Thabit D., 1976 Hydrogeology of river test catchments in Hampshire. Unpublished M. Sc. Thesis, University of London 161p.

Meyboom, P., 1961. Estimating Ground-Water Recharge from Stream Hydrographs. Journal of Geophysical Research, 66(4), pp. 1203-1214.

MSN, Search Encarta About, 2006 Encyclopedia Article, Tigris. Available at www. encarea. msn.com/encyclopedia_761574188/tigris.html.

Raghunath. H. M., 2006. Hydrology. Principles. Analysis. Design. Second Edition. New AGE. INTERNATIONAL (P) Limited, Publishers. 463P.

Reddy, J. R., 2005. A Text Book of Hydrology. IAXMI PULICATIONCPJ LTD. 530P.

UNEP, United Nations Environment Program, 2001. The Mesopotamian Marshland: Demise of an Ecosystem. Early Warning and Assessment Technical Rreport. UNEP/DEWA/TR.01-3. 47P.

Warren, Viessman and Gary, Lewis. 2007. Introduction to Hydrology. $5^{\text {th }}$ Ed. Laroisier . $612 \mathrm{P}$.

Wikipedia, 2007. Wikipedia, the Free Encyclopedia, Tigris. Available at www.en.wikipedia.org/wiki/Tigris 